\title{
Diversity of Aquatic and Terrestrial Molluses from Simeulue Island, with Notes on Their Distribution and Some New Records
}

\author{
NOVA MUJIONO*, RISTIYANTI M MARWOTO, HERYANTO \\ Research Center for Biology - Indonesian Institute of Sciences \\ Jl. Raya Jakarta-Bogor Km. 46 Cibinong, Bogor, West Java, Indonesia. 16912 \\ *Email: nova.mzb@gmail.com
}

Received 9 March 2020; Received in revised form 28 April 2020;

Accepted 14 May 2020; Available online 30 June 2020

\begin{abstract}
Faunistic study on the malacofauna of Simeulue Island was carried out in 2017 after 104 years from the last collection in 1913. Three locations with 13 stations were observed. 20 families and 50 species of aquatic and terrestrial molluscs were identified. The occurrences of four local endemic species were still found and 19 new distributional records were added to the previous list. However, five previously listed species were not found in the present study. Through the present study, the accumulative number of malacofauna from Simeulue Island will be around 54 species. 19 species were reported for the first time, including three introduced species and one new records for Indonesia. Four local endemic species were still found there after 104 years gone by.
\end{abstract}

Keywords: distribution; endemic; malacofauna; Simeulue Island

\section{INTRODUCTION}

Simeulue (Simalur) is a small island located on the west coast of Sumatra Island. The distance between Simeulue to mainland Sumatra is about $136 \mathrm{~km}$. The island extent approximately 183.809 ha. Simeulue is a regency in the Aceh province and covers 10 districts and 138 villages with the capital in Sinabang (District Simeulue Timur). Simeulue has a hilly topography. Most areas are located at an altitude between 0-300 masl. Hilly areas with slopes below $18^{\circ}$ are located in the central part of the island, especially in the mountainous regions to the north and south. The climate is classified in the wet tropical climate zone with temperatures ranging from $23^{\circ}-34.5^{\circ} \mathrm{C}$ and a daily average between $25^{\circ}-27^{\circ} \mathrm{C}$. The average annual rainfall is quite high, $3.884 \mathrm{~mm} /$ year. The rainy season generally occurs between September-February, while the dry season is generally between March-August. The lowest rainfall occurs in June, while the highest rainfall occurs in March (BPS-Statistics of Simeulue Regency, 2019).

Naturally, several species could only be distributed in a narrow range or a small area (Isik, 2011). The diversity of habitat types in Simeulue Island makes it suitable for various types of animals, which has attracted foreign researchers' interest. Dr. WL Abbott from
America, a medical doctor, and an ornithologist first explored Simeulue Island (November 1901-January 1902). A few years later, Dr. E Jacobson also came to Simeulue Island in 1913 and collected several groups of animals, including molluscs. Based on that collection, Laidlaw (1954; 1957) listed 24 species. Later, van Benthem-Jutting (1959) added more species become 40 species.

No more molluscs collection has been made on Simeulue Island since Dr. E Jacobson in 1913. There is a change in the species composition of molluscs after more than 100 years. For this reason, the current study is needed to determine the composition of molluscs on Simeulue Island because the small island is prone to disasters such as tsunamis (Whitlow, 2008). The small island is also susceptible to experience the extinction of its biota caused by climate change or disaster, including molluscs (Cowie, 1992; Regnier et al., 2009).

\section{MATERIALS AND METHODS}

An explorative method using a purposive sampling technique was applied in this study. Three locations were selected: District Teupah Tengah (St.1); District Simeulue Timur (St.2St.9), and District Alafan (St.10-St.13), shown in Figure 1. 


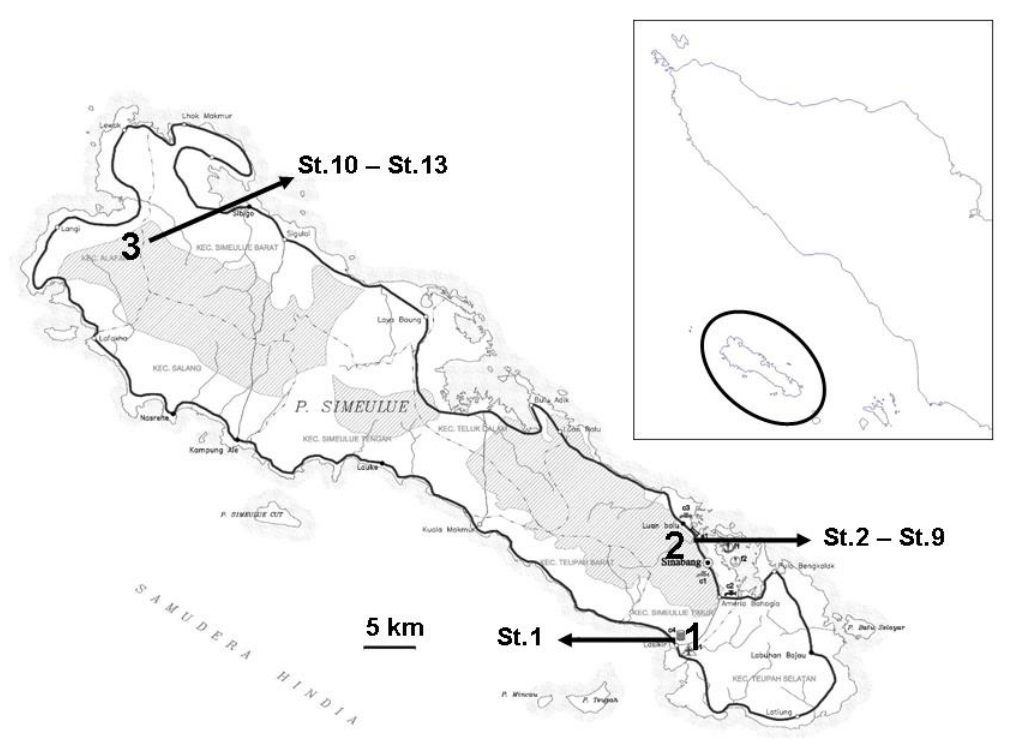

Figure 1. Map of Simeulue Island with the three locations in this study

The collection of specimens was carried out at 13 collection stations. Collecting stations are listed in Table 1. Based on their habitat type, 13 collection stations were classified as: forest (St.2, St.3, St.4, St.11, and St.13), near the settlement (St.9), freshwater river (St.1, St.6, St.7, St.8, and St.10), estuarine (St.12), near the beach (St.5). Molluscs were sampled in their preferred habitats, such as branches/tree trunks, leaf litter, rotten wood trunks, rock/soil cracks (Pearce \& Orstan, 2006), and also shallow and clear waters for aquatic molluscs (Dillon,
2006). At each collection station of various sizes, sample collection was carried out for 2 hours using a visual searching method (Cameron \& Pokryszko, 2005). Samples were taken using forceps and put into plastic ziplock accompanied by the collection station's coordinate data. Samples were preserved in $70 \%$ alcohol to be identified and stored at the Bogor Zoological Museum. Museum collections were used as references for identification.

Table 1. Geographic position and habitat of molluscs

\begin{tabular}{|c|c|c|c|}
\hline Station & Administrative & Habitat & Coordinates \\
\hline 1 & $\begin{array}{l}\text { Lasikin Airport area, } \\
\text { District Teupah Tengah }\end{array}$ & $\begin{array}{l}\text { Freshwater river: small stream, width } 1 \mathrm{~m} \text {, with } \\
\text { concrete wall, depth } 15 \mathrm{~cm} \text {, slow current, rocky } \\
\text { and muddy bottoms }\end{array}$ & $\begin{array}{l}\mathrm{N} 02^{\circ} 24 ' 31,63^{\prime \prime} \mathrm{E} \\
96^{\circ} 19^{\prime} 44.25 " 2 \text { masl }\end{array}$ \\
\hline 2 & $\begin{array}{l}\text { Kuala Makmur village, } \\
\text { District Simeulue Timur }\end{array}$ & Forest: forest close to the first base camp & $\begin{array}{l}\mathrm{N} 02^{\circ} 32^{\prime} 27,28^{\prime \prime} \mathrm{E} \\
96^{\circ} 17^{\prime} 00.85^{\prime} 75 \text { masl }\end{array}$ \\
\hline 3 & $\begin{array}{l}\text { Kuala Makmur village, } \\
\text { District Simeulue Timur }\end{array}$ & Forest: forest close to the soccer field & $\begin{array}{l}\mathrm{N} 02^{\circ} 32^{\prime} 50,70 ” \mathrm{E} \\
96^{\circ} 17^{\prime} 48.14 ” 53 \text { masl }\end{array}$ \\
\hline 4 & $\begin{array}{l}\text { Kuala Makmur village, } \\
\text { District Simeulue Timur }\end{array}$ & Forest: forest close to a water spring & $\begin{array}{l}\mathrm{N} 02^{\circ} 32^{\prime} 24,39 ” \mathrm{E} \\
96^{\circ} 16^{\prime} 12.93 ” 139 \text { masl }\end{array}$ \\
\hline 5 & $\begin{array}{l}\text { Langgi village, District } \\
\text { Simeulue Timur }\end{array}$ & $\begin{array}{l}\text { Near the beach: field close to Teluk Nibung } \\
\text { beach }\end{array}$ & $\begin{array}{l}\mathrm{N} 02^{\circ} 344^{\prime} 35,93 " \mathrm{E} \\
96^{\circ} 15^{\prime} 56.111^{\prime \prime} 0 \text { masl }\end{array}$ \\
\hline 6 & $\begin{array}{l}\text { Air Pinang village, District } \\
\text { Simeulue Timur }\end{array}$ & $\begin{array}{l}\text { Freshwater river: under the bridge of unnamed } \\
\text { river, width } 5 \mathrm{~m} \text {, depth } 45 \mathrm{~cm} \text {, medium current, } \\
\text { rocky and sandy bottoms }\end{array}$ & $\begin{array}{l}\mathrm{N} 02^{\circ} 35^{\prime} 22,90 ” \mathrm{E} \\
96^{\circ} 14^{\prime} 51.38^{\prime \prime} 12 \text { masl }\end{array}$ \\
\hline 7 & $\begin{array}{l}\text { Air Pinang village, District } \\
\text { Simeulue Timur }\end{array}$ & $\begin{array}{l}\text { Freshwater river: small roadside ditch, width } \\
0,4 \mathrm{~m} \text {, depth } 5 \mathrm{~cm} \text {, slow current, rocky and } \\
\text { muddy bottoms }\end{array}$ & $\begin{array}{l}\mathrm{N} 02^{\circ} 35^{\prime} 15,87^{\prime \prime} \mathrm{E} \\
96^{\circ} 144^{\prime} 57,00^{\prime \prime} 15 \text { masl }\end{array}$ \\
\hline 8 & $\begin{array}{l}\text { Ujung Tinggi village, } \\
\text { District Simeulue Timur }\end{array}$ & $\begin{array}{l}\text { Freshwater river: a roadside river, width } 3 \mathrm{~m} \text {, } \\
\text { depth } 30 \mathrm{~cm} \text {, slow current, rocky and muddy } \\
\text { bottoms }\end{array}$ & $\begin{array}{l}\mathrm{N} 02^{\circ} 34 ’ 18,39 ” \mathrm{E} \\
96^{\circ} 16^{\prime} 27.10 ” 10 \text { masl }\end{array}$ \\
\hline
\end{tabular}




\begin{tabular}{|c|c|c|c|}
\hline 9 & $\begin{array}{l}\text { Ameria Bahagia village, } \\
\text { District Simeulue Timur }\end{array}$ & $\begin{array}{l}\text { Near the settlement: around the Wisma Harti } \\
\text { inn }\end{array}$ & $\begin{array}{l}\mathrm{N} 02^{\circ} 27^{\prime} 55,71^{\prime \prime} \mathrm{E} \\
96^{\circ} 22^{\prime} 41.58^{\prime \prime} 6 \text { masl }\end{array}$ \\
\hline 10 & $\begin{array}{l}\text { Langi village, District } \\
\text { Alafan }\end{array}$ & $\begin{array}{l}\text { Freshwater river: Nanglis river, Width } 1,5 \mathrm{~m} \text {, } \\
\text { depth } 40 \mathrm{~cm} \text {, slow current, rocky and sandy } \\
\text { bottoms }\end{array}$ & $\begin{array}{l}\mathrm{N} 02^{\circ} 49^{\prime} 09,65^{\prime \prime} \mathrm{E} \\
95^{\circ} 466^{\prime} 20.64 " 32 \text { masl }\end{array}$ \\
\hline 11 & $\begin{array}{l}\text { Langi village, District } \\
\text { Alafan }\end{array}$ & Forest: forest close to the second base camp & $\begin{array}{l}\mathrm{N} 02^{\circ} 49^{\prime} 00,73 ” \mathrm{E} \\
95^{\circ} 45^{\prime} 01.899^{\prime} 38 \text { masl }\end{array}$ \\
\hline 12 & $\begin{array}{l}\text { Langi village, District } \\
\text { Alafan }\end{array}$ & $\begin{array}{l}\text { Estuarine: downstream of Simalandel river, } \\
\text { width } 10 \mathrm{~m} \text {, depth } 35 \mathrm{~cm} \text {, slow current, rocky } \\
\text { and muddy bottoms }\end{array}$ & $\begin{array}{l}\mathrm{N} 02^{\circ} 49^{\prime} 17,32^{\prime \prime} \mathrm{E} \\
95^{\circ} 45^{\prime} 28.32^{\prime \prime} 2 \text { masl }\end{array}$ \\
\hline 13 & $\begin{array}{l}\text { Langi village, District } \\
\text { Alafan }\end{array}$ & $\begin{array}{l}\text { Forest: Nypa fruticans forest, flooded with } \\
\text { freshwater, muddy bottoms }\end{array}$ & $\begin{array}{l}\mathrm{N} 02^{\circ} 49^{\prime} 05,11 \text { ' E } \\
95^{\circ} 45^{\prime} 25.10^{\prime \prime} 17 \text { masl }\end{array}$ \\
\hline
\end{tabular}

Data on species lists and their occurrences were examined with three previous studies (Laidlaw, 1954; Laidlaw, 1957; van BenthemJutting, 1959). If a species is not listed in these references, it is considered 'New Record' for Simeulue Island. Species distribution in mainland Sumatra or neighboring islands (Java, Borneo) also will be discussed briefly. Data on species occurrence were transferred into the binary matrix (present: 1, absent: 0). This binary data will be used in cluster analysis using UPGMA and Kulczynski similarity index (Höltke et al., 2016). The analysis was conducted with 10.000 bootstrap replicates and shown in dendrogram (Efron et al., 1996). The cophenetic correlation coefficient (r) was used to measure how faithfully a dendrogram preserves the pairwise distances between the original data points (Saraçli et al., 2013). Their categories were: $r>0.9$ (very good fit), $0.8<r$ $<0.9$ (good fit), $0.7<\mathrm{r}<0.8$ (poor fit), and $\mathrm{r}<$ 0.7 (very poor fit)(Rohlf \& Fisher, 1968). All of the analysis was performed in PAST $2.17 \mathrm{c}$ (Hammer et al., 2001).

\section{RESULT AND DISCUSSION}

Two molluscan classes were observed: freshwater Bivalvia and terrestrial and aquatic Gastropoda. A total of 1934 molluscs specimens were collected, separated into 1589 aquatic and 345 terrestrial molluscs. Aquatic molluscs consisted of one family and two species of freshwater bivalves, and seven families and 25 species of gastropods (Table 2).

Table 2. Diversity of aquatic molluscs found in this study

\begin{tabular}{|c|c|c|c|c|c|c|c|c|c|c|c|c|c|c|}
\hline \multirow{2}{*}{ No. } & \multirow{2}{*}{ Family/Species } & \multicolumn{8}{|c|}{ Station Observed } & \multirow{2}{*}{$\mathbf{N}$} & \multirow{2}{*}{ D } & \multirow{2}{*}{$\mathbf{S}$} & \multirow{2}{*}{$\mathbf{J}$} & \multirow{2}{*}{ B } \\
\hline & & 1 & 4 & 6 & 7 & 8 & 10 & 12 & 13 & & & & & \\
\hline I & CYRENIDAE (Bivalvia) & & & & & & & & & & & & & \\
\hline 1 & Batissa violacea* & 7 & & & & & & & & 7 & 1 & + & + & + \\
\hline 2 & Geloina expansa* & & & & & & & 6 & & 6 & 1 & + & + & + \\
\hline II & AMPULLARIIDAE & & & & & & & & & & & & & \\
\hline 3 & Pomacea canaliculata* & 5 & & & & & & & & 5 & 1 & + & + & + \\
\hline III & BULINIDAE & & & & & & & & & & & & & \\
\hline 4 & Indoplanorbis exustus* & & & & 16 & & & & & 16 & 1 & + & + & + \\
\hline IV & NERITIDAE & & & & & & & & & & & & & \\
\hline 5 & Clithon corona & 40 & & 142 & & 4 & & & & 186 & 3 & + & + & \\
\hline 6 & Neripteron auriculatum & 1 & & & & & & & & 1 & 1 & + & + & \\
\hline 7 & Neritina pulligera & 41 & & 4 & & 10 & 6 & & & 61 & 4 & + & + & \\
\hline 8 & Neritodryas cornea* & & 9 & & & & & & 24 & 33 & 2 & + & + & \\
\hline 9 & N. subsulcata & & & 12 & & & & & & 12 & 1 & + & + & \\
\hline 10 & Septaria tesselata & & & 1 & & & & & & 1 & 1 & + & + & \\
\hline 11 & Vittina turrita & 3 & & & & & & 198 & 7 & 208 & 3 & + & + & \\
\hline 12 & V. variegata & 78 & & 6 & & 59 & 21 & 100 & & 264 & 5 & + & + & + \\
\hline IV & PACHYCHILIDAE & & & & & & & & & & & & & \\
\hline 13 & Faunus ater* & & & 12 & & & & 13 & & 25 & & + & + & \\
\hline $\mathrm{V}$ & PLANORBIDAE & & & & & & & & & & & & & \\
\hline 14 & Ferrissia javana* & & & & 227 & & & & & 227 & 1 & + & + & \\
\hline VII & THIARIDAE & & & & & & & & & & & & & \\
\hline
\end{tabular}




\begin{tabular}{|c|c|c|c|c|c|c|c|c|c|c|c|c|c|c|}
\hline 15 & Melanoides tuberculata & 13 & & & 3 & 7 & 11 & & 82 & 116 & 5 & + & + & + \\
\hline 16 & Mieniplotia scabra & & & & & & & & 1 & 1 & 1 & + & + & + \\
\hline 17 & Sermyla riqueti & & & & & & & 227 & & 227 & 1 & + & + & \\
\hline 18 & Stenomelania macilenta & & & 8 & & & & & & 8 & 1 & + & + & \\
\hline 19 & S. plicaria* & & & 37 & & 3 & & & 6 & 46 & 3 & + & + & \\
\hline 20 & S. punctata* & & & & & 29 & & 67 & & 96 & 2 & + & + & \\
\hline 21 & S. rustica & & & & & & 12 & & 5 & 17 & 2 & + & + & \\
\hline 22 & S. torulosa* & & & 4 & & & & & & 4 & 1 & + & + & \\
\hline 23 & Tarebia granifera & 14 & & & & & & & & 14 & 1 & + & + & + \\
\hline 24 & Thiara amarula & & & & & & & & 1 & 1 & 1 & + & + & \\
\hline 25 & T. aspera* & & & 7 & & & & & & 7 & 1 & + & + & \\
\hline & number of species & 9 & 1 & 10 & 3 & 6 & 4 & 6 & 7 & & & 24 & 25 & 8 \\
\hline & number of specimens & 202 & 9 & 233 & 246 & 112 & 50 & 611 & 126 & 1589 & & & & \\
\hline
\end{tabular}

Notes: aquatic molluscs were absent in Stations 2, 3, 5, 9, 11; *: New record. N= number of specimens. $\mathrm{D}=$ distribution in 13 stations; $\mathrm{S}$ (Sumatra), J (Java), B (Borneo); += present.

Meanwhile, terrestrial molluscs consisted of 12 families and 25 species of gastropods (Table 3). Species compositions between 13 stations observed were greatly varied. The most species-rich station was St.4, with 17 species observed, while only one species was observed in St.5, St.4 is a forest where there is a water spring in which the evaporation of it increases the surrounding humidity. Gastropods prefer habitats with high humidity, so many species are found here. St. 5 is a field close to the coast of Teluk Nibung, not connected to the forest. There is an asphalt road isolating St.5 from the coastal habitat. The occurrence of Pythia undata (Ellobiidae), a resident of the mangrove ecosystem, shows that there was once mangrove vegetation that is currently disappearing.

Table 3. Diversity of terrestrial molluscs found in this study

\begin{tabular}{|c|c|c|c|c|c|c|c|c|c|c|c|c|c|c|c|}
\hline \multirow{2}{*}{ No. } & \multirow{2}{*}{ Family/Species } & \multicolumn{9}{|c|}{ Station Observed } & \multirow{2}{*}{$\mathbf{N}$} & \multirow{2}{*}{ D } & \multirow{2}{*}{$\mathbf{S}$} & \multirow{2}{*}{$\mathbf{J}$} & \multirow{2}{*}{ B } \\
\hline & & 1 & 2 & 3 & 4 & 5 & 9 & 10 & 11 & 13 & & & & & \\
\hline I & ACHATINIDAE & & & & & & & & & & & & & & \\
\hline $\mathbf{1}$ & Paropeas achatinaceum* & & & & & & 5 & & & & 5 & 1 & + & + & + \\
\hline 2 & Subulina octona & & & & & & 26 & & & & 26 & 1 & + & + & + \\
\hline II & ARIOPHANTIDAE & & & & & & & & & & & & & & \\
\hline 3 & Hemiplecta humphreysiana & & & & & & & 1 & & & 1 & 1 & + & + & + \\
\hline 4 & H. simalurensis ${ }^{\#}$ & & 5 & 4 & 4 & & & & 2 & & 15 & 4 & & & \\
\hline 5 & Macrochlamys amboinensis* & & 1 & 16 & 4 & & 1 & & & & 22 & 4 & + & + & \\
\hline 6 & M. spectabilis* & & 13 & 5 & 1 & & & 3 & & 2 & 24 & 5 & & & \\
\hline 7 & Taphrospira sp. & & 2 & 39 & 5 & & & & & & 46 & 3 & & & \\
\hline III & CAMAENIDAE & & & & & & & & & & & & & & \\
\hline 8 & $\begin{array}{l}\text { Amphidromus sumatranus } \\
\text { jacobsoni }\end{array}$ & & 2 & & 2 & & & & & & 4 & 2 & & & \\
\hline 9 & A. webbi babiensis & & & & 2 & & & & & & 2 & 1 & & & \\
\hline 10 & A. webbi simalurensis ${ }^{\#}$ & & 4 & 1 & 2 & & & 2 & & & 9 & 4 & & & \\
\hline IV & CYCLOPHORIDAE & & & & & & & & & & & & & & \\
\hline 11 & Cyclohelix crocata jacobsoni & & 9 & & 12 & & & 2 & 1 & & 24 & 4 & & & \\
\hline 12 & C. kibleri simalurensis & & & 5 & & & & & & & 5 & 1 & & & \\
\hline 13 & Cyclophorus schepmani ${ }^{\#}$ & & 6 & 6 & 10 & & & 2 & & & 24 & 4 & & & \\
\hline 14 & Leptopoma niasense & & 1 & 8 & 6 & & & & 1 & & 16 & 4 & & & \\
\hline 15 & Theobaldius dautzenbergi & & 3 & 3 & 1 & & & & 2 & & 9 & 4 & + & & \\
\hline $\mathrm{V}$ & DYAKIIDAE & & & & & & & & & & & & & & \\
\hline 16 & Sasakina oxyconus* & & & & 1 & & & & & & 1 & 1 & & & \\
\hline VII & ELLOBIIDAE & & & & & & & & & & & & & & \\
\hline 17 & Pythia undata* & & & & & 31 & & & & 2 & 33 & 2 & & + & + \\
\hline VIII & HELICARIONIDAE & & & & & & & & & & & & & & \\
\hline 18 & Helicarion albellus* & & & & & & 5 & & & & 5 & 1 & + & + & + \\
\hline 19 & H. hyaleus & & 9 & 2 & 1 & & & 4 & 5 & & 21 & 5 & + & & \\
\hline
\end{tabular}




\begin{tabular}{|c|c|c|c|c|c|c|c|c|c|c|c|c|c|c|c|}
\hline IX & HELICINIDAE & & & & & & & & & & & & & & \\
\hline 20 & Sulfurina behniana & 1 & & 18 & 20 & & & & & & 39 & 3 & + & & \\
\hline 21 & S. bensoni & & 1 & 1 & 3 & & & & & & 5 & 3 & & & \\
\hline $\mathrm{X}$ & STREPTAXIDAE & & & & & & & & & & & & & & \\
\hline 22 & Gulella bicolor* & & & & & & 2 & & & & 2 & 1 & + & + & + \\
\hline $\mathrm{XI}$ & TROCHOMORPHIDAE & & & & & & & & & & & & & & \\
\hline 23 & Videna crassicarinata & & 1 & & & & & & & & 1 & 1 & & & \\
\hline 24 & V. niasensis & & & & 2 & & & & 2 & & 4 & 2 & & & \\
\hline XII & VERONICELLIDAE & & & & & & & & & & & & & & \\
\hline 25 & Filicaulis bleekeri* ${ }^{*}$ & & & & & & 2 & & & & 2 & 1 & + & + & + \\
\hline & number of species & 1 & 13 & 12 & 16 & 1 & 4 & 6 & 6 & 2 & & & 10 & 8 & 7 \\
\hline & number of specimens & 1 & 57 & 108 & 76 & 31 & 10 & 14 & 13 & 4 & 345 & & & & \\
\hline
\end{tabular}

Notes: terrestrial molluscs were absent in Stations $6,7,8,12 ; *=$ New record; ${ }^{\#}=$ endemic for Simeulue Island; N= number of specimens; $D=$ distribution in 13 stations; $\mathrm{S}$ (Sumatra), J (Java), B (Borneo); += present.

The two most diverse families for aquatic molluscs were Thiaridae (11 species) and Neritidae (8 species). While for terrestrial molluscs were Ariophantidae and Cyclophoridae, each with 5 species. Aquatic molluscs were absent in Stations 2, 3, 5, 9, and 11. Meanwhile, terrestrial molluscs were absent in Stations 6, 7, 8, and 12. The previous study in Sumatran molluscs has listed 30 species of Neritidae, 15 species of Thiaridae, 14 species of Ariophantidae, and 37 species of Cyclophoridae. Meanwhile, 40 molluscs species were listed from Simeulue Island (van Benthem-Jutting, 1959). The total area of Simeulue Island is 183.809 ha, while Sumatra Island extends 47.348 .100 ha. Simeulue is only around $0.39 \%$ of Sumatra. Commonly, the number of species will increase following the size of the island. This pattern is called the theory of island biogeography. Because the habitat in a small island (Simeulue) is less varied than the mainland (Sumatra), a small island can only support fewer species. Isolation by distance (136 km from Sumatra) often supports unique species assemblages, especially rare and endemic species with smaller population sizes (Guo, 2015).

The species richness in the three locations widely varied. Ten species were identified from St. 1 in location 1, 24 species from four stations in location 3, and 39 species from eight stations in location 2. Diversity seems to increase following the number of stations observed. This pattern is termed the species-area relationship (SAR)(Azovsky, 2011).

Local distributions between three locations and 13 collection stations also differ greatly.
Almost half (24 of 50) of the species were only found in one station. Meanwhile, species found in 2, 3, and 4 stations were similar, each with two species. Four species (V. variegata, $M$. tuberculata, $M$. spectabilis, $H$. hyaleus) were found in 5 stations and become the most widely distributed species. $V$. variegata and $M$. tuberculata are purely freshwater species. They cannot stand or less tolerance to estuarine or marine water (van Benthem-Jutting, 1956). Four species that can tolerate estuarine water are $S$. riqueti, $F$. ater, $C$. corona, and $V$. turrita (Mujiono, 2016). The previous study in Vanuatu Islands, South Pacific, showed that $V$. variegata was found in five islands, while $M$. tuberculata was found in all the areas (Haynes, 2000). The distribution record of $V$. variegata from Sumatra was only from the northern part (Belawan, near Medan, North Sumatra). Meanwhile, M. tuberculata was recorded from the northern, central, and southern parts of Sumatra. Both species also can be found in Java and Borneo (van Benthem-Jutting, 1959).

There were six species ( $P$. achatinaceum, S. octona, $H$. albellus, F. bleekeri, G. bicolor, and $M$. amboinensis) found near the settlement (St.9). Between them, only M. amboinensis that also found in the forest. The natural forest is the native habitat of $M$. amboinensis (van Benthem-Jutting, 1952). This shows that St.9 was once a forest that has now been turned into a settlement. Six species (V. turrita, $V$. variegata, $F$. ater, S. punctata, S. riqueti, and G. expansa) were found in estuarine (St.12). However, only two last species that truly estuarine. Four other species also found in freshwater river or forest. Only one species 
(Pythia undata) was found near the beach (St.5). However, this species is also found in the forest (St.13), dominated by Nypa fruticans, a mangrove plant. Pythia undata was also observed in St.5, which used to be a mangrove habitat.

Based on the dendrogram from cluster analysis, 13 stations can be classified into two groups (Figure 2). Group 1 mainly consists of stations with terrestrial habitat, except in St.10 (Nanglis river, Langi village, District Alafan). There were 10 species observed in this station. However, it consists of six terrestrial and four aquatic molluscs. Five aquatic species are also present in Group 1 (St.4: Neritodryas cornea, St.10: Neritina pulligera, Vittina variegata, Melanoides tuberculata, and Stenomelania rustica). Those species are accidentally found in the stream close to St.4 and St.10. Within Group 1, St.2, St.4, and St.3 were grouped with $78 \%$ similarity; other stations were below $56 \%$. St.2, St.4, and St.3 were located in the same village (Kuala Makmur village, District Simeulue Timur). Because their position is close to each other, species composition between them is relatively similar. There were 17 species observed in these stations, 10 species present in 3 stations, one species present in St. 2 and St.4, one species present in St.3 and St.4. The other five species are only present in a single station. The dendrogram also shows that the species composition in the southern part (location 1 and 2, St.1-St.9) and the northern part (location 3, St.10-St.13) is mixed, as seen in the occurrences of 18 species. No separation exists between the three locations observed.

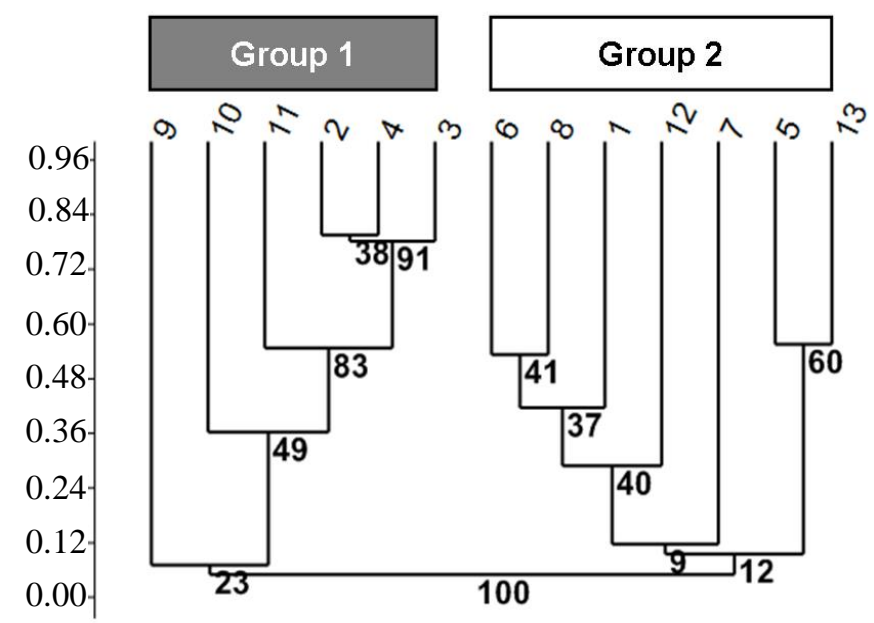

Figure 2. Dendrogram from cluster analysis using Kulczynski similarity index. Cophenetic correlation coefficient (r): 0.91 (very good)

Group 2 mainly consists of stations with aquatic habitat, except in St.5 (field close to Teluk Nibung beach. Linggi village, District Simeulue Timur). Only one species (Pythia undata) was observed in this station, and it is a terrestrial (arboreal) species. Three terrestrial species are also present in Group 2 (St.1: Sulfurina behniana, St.13: Macrochlamys spectabilis, while Pythia undata present in St.5 and St.13). Those three species are arboreal and can climb a tree or shrub near the riverbanks or streams (Vermeulen \& Whitten, 1998). Within Group 2, St. 6 and St. 8 were grouped with 54\% similarity since four species are present in both stations from 12 species observed. St.6 and St.7 were located in the same village (Air Pinang village, District Simeulue Timur), while St. 8 is located in Ujung Tinggi village, District Simeulue Timur. However, there are no similar species present in St.6 and St.7.

Molluscs are slow-moving animals and depend on their preferred habitat. The small island with only a few habitat variations tends to limit their geographic distribution, especially in terrestrial species. From 25 species found in this study, ten species are also found in mainland Sumatra, eight species found in Java, seven species found in Borneo, and only six species that are found in Sumatra, Java, and 
Borneo. Marine really acts as the barrier for terrestrial gastropods distribution.

Different from their terrestrial relatives, aquatic molluscs have a wider geographic distribution. All aquatic molluscs in this study are also found in mainland Sumatra and Java (van Benthem-Jutting, 1959; Hamidah, 2004). Even eight species from five families (Cyrenidae, Ampullariidae, Bulinidae, Neritidae, Thiaridae) are also found in Borneo. Members of the family Neritidae are marine and have planktonic larvae on their reproduction cycle. These larvae will drift in freshwater systems and broaden their distribution (Kappes \& Haase, 2012). Freshwater molluscs also can be dispersed as juveniles or adults by water birds and mammals. Some pelagic birds migrate long distances and accidentally bring the molluscs attached to their legs or wings (van Leeuwen et al., 2013).

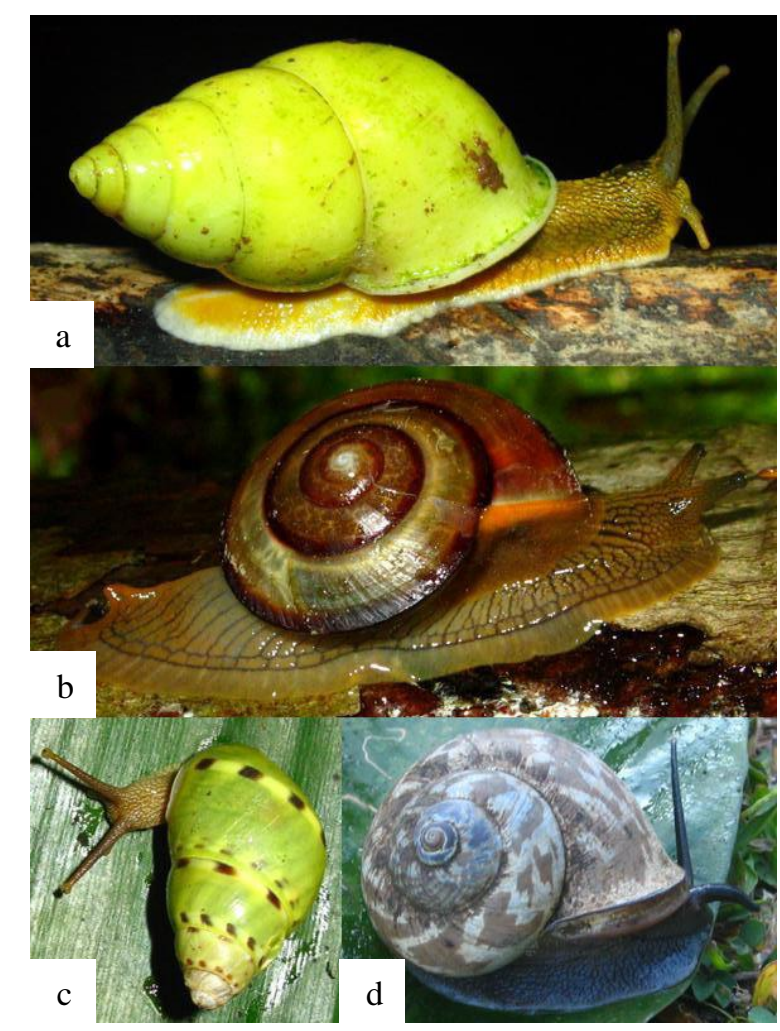

Figure 3. Endemic terrestrial gastropods of Simeulue Island: a. A. webbi simalurensis; b. H. Simalurensis; c. A. sumatranus jacobsoni; d. C. schepmani

There are four local endemic species, include $A$. sumatranus jacobsoni, A. webbi simalurensis, $H$. simalurensis, and $C$. schepmani (Laidlaw, 1954; Laidlaw, 1957)(Figure 3). Some other species are not locally endemic for Simeulue Island because they are also found on the neighboring island. Taphrospira sp. is also found in Weh Island, located in the north of Banda Aceh. A. webbi babiensis, C. crocata jacobsoni, and $C$. kibleri simalurensis are also found in Babi Island, located on the south of the island. $V$. crassicarinata, $V$. niasensis, and L. niasensis are also found in Nias Island, located on the south of the island. S. bensoni is also found in Lekon Island, located on the south of the island (Laidlaw, 1954, Laidlaw, 1957; van BenthemJutting, 1959). Because these species have the distribution of more than in one small island, they can be categorized as provincial endemic (restricted within the borders of a province)(Isik, 2011), even though those neighboring islands are administratively not in the same province.

There are 19 molluscs species newly recorded from Simeulue Island, consisting of 11 aquatic and eight terrestrial molluscs. Within aquatic molluscs, four species (B. violacea, $G$. 
expansa, P. canaliculata, and I. exustus) are previously recorded from Sumatra, Java, and Borneo. In comparison, seven other species $(N$. cornea, $F$. ater, $F$. javana, $S$. plicaria, $S$. punctata, $S$. torulosa, and $T$. aspera) are previously recorded from Java, and Borneo. Two bivalves ( $B$. violacea and $G$. expansa) have planktonic larvae on their life cycle, so they are widely distributed. I. exustus is also widely distributed across India, Southeast Asia, Central Asia (Afghanistan), Arabia, and Africa (Liu et al., 2010). P. canaliculata is native to South America, introduced to Indonesia through aquarium trade around 1986. Now this species has spread in all the Indonesian main islands (Marwoto et al., 2018).

Four terrestrial gastropods species ( $P$. achatinaceum, $H$. albellus, G. bicolor, and $F$. bleekeri) were previously recorded from Sumatra, Java, and Borneo, M. amboinensis previously recorded from Sumatra and Java, $P$. undata is previously recorded from Java and Borneo (van Benthem-Jutting, 1959). Three introduced species were identified: $G$. bicolor was native to India, S. octona was native to the Neotropics, while the origin of M. amboinensis is still unknown (Nurinsiyah \& Hausdorf, 2019). S. oxyconus was previously recorded from Lesser Sunda Islands (Lombok, Sumba, and Sumbawa). However, this species is absent in Bali, Java, and Sumatra (Rensch, 1932). M. spectabilis was previously recorded from Samar Island, Philippines (Faustino, 1930) and never recorded before in Indonesia. Two or more groups that are related but considerably separated from each other geographically is termed as disjunct distribution. Another case of disjunct distribution can be seen in Carinigera buresi (Clausiliidae) in Europe, which is separated over $200 \mathrm{~km}$ (Uit de Weerd \& Gittenberger, 2019).

This study adds a significant number of species to the malacofauna of Simeulue Island. However, there are five species of terrestrial and freshwater gastropods (Pseudonenia jacobsoni, Planspira quadrivolvis, Pupina degneri, Cyclohelix nicobarica, and Septaria lineata), which were previously recorded by van Benthem-Jutting (1959) but not found in this study. Through the present study, the diversity of molluscs species in Simeulue Island accumulates in approximately 54 species.

\section{CONCLUSION}

The present study documents 50 molluscan species, consisting of 25 freshwater and 25 terrestrial molluscs. 17 species were observed in St.4, a forest with a water spring. In comparison, only one species was observed in St.5, isolated, and degraded mangrove vegetation. Four local endemic species are still found in the area, and 19 species were identified as new records for the island. Species composition from the northern and southern parts of the island seems to be similar. However, five previously known species are not observed. Through the present study, the total number of malacofauna from Simeulue Island sets around 54 species. Further study in a longer period of time is needed to uncover the hidden molluscan diversity from other localities with no recent scientific background.

\section{ACKNOWLEDGEMENTS}

The author would like to thank all the team members of "Ekspedisi Bioresources LIPI 2017: Pulau Simeulue, Aceh" for their kindness during the field survey. Alfiah and $\mathrm{R}$ Priehandini (MZB) for their assistance during the laboratory work, and all the reviewers for their constructive advice.

\section{REFERENCES}

Azovsky AI. 2011. Species-area and species-sampling effort relationships: disentangling the effects. Ecography. vol 34(1): 18-30. doi: https://doi.org/10.1111/j.16000587.2010.06288.x.

BPS-Statistics of Simeulue Regency. 2019. Simeulue Regency in Figures 2019. Simeulue: BPSStatistics of Simeulue Regency. pp 387.

Cameron RAD, Pokryszko BM. 2005. Estimating the species richness and composition of land mollusc communities: Problems, consequences and practical advice. Journal of Conchology. vol 38(5): 529-547.

Cowie RH. 1992. Evolution and extinction of Partulidae, endemic Pacific Island land snails. Philosophical Transactions: Biological Sciences. vol 335(1274): 167-191. doi: https://doi.org/10.1098/rstb.1992.0017.

Dillon RT. 2006. Freshwater gastropoda. In: Sturm CF, Pearce TA, Valdes A (eds). The Mollusks: A 
Guide to Their Study, Collection, and Preservation. Pittsburgh: American Malacological Society. pp 251-259.

Efron B, Halloran E, Holmes S. 1996. Bootstrap confidence levels for phylogenetic trees. Proceeding of the National Academy of Sciences United States of America. vol 93: 13429-13434. doi: https://doi.org/10.1073/pnas.93.23.13429.

Faustino LA. 1930. Summary of Philippine land shells. Philippine Journal of Science. vol 42(1): 85-198.

Guo Q. 2015. Island Biogeography Theory: Emerging Patterns and Human Effects. In Reference Module in Earth Systems and Environmental Sciences. Amsterdam: Elsevier Inc. doi: https://doi.org/10.1016/b978-0-12-4095489.09419-7.

Hamidah A. 2004. Keanekaragaman dan kelimpahan komunitas gastropoda di Sungai Ogan Kabupaten Ogan Komering Ulu. Jurnal Penelitian Sains. vol 16: 60-67. doi: https://doi.org/10.26554/jps.v0i16.266.

Hammer $\varnothing$, Harper DAT, Ryan PD. 2001. Past: Paleontological Statistics software package for education and data analysis. Palaeontologia Electronica. vol 4(1):1-9.

Haynes A. 2000. The distribution of freshwater gastropods on four Vanuatu islands: Espíritu Santo, Pentecost, Éfate and Tanna (South Pacific). Annales de Limnology. vol 36(2): 101-111. doi: https://doi.org/10.1051/limn/2000006.

Höltke O, Salvador RB, Rasser MW. 2016. Paleobiogeography of Early/Middle Miocene terrestrial gastropods in Central Europe: An approach using similarity indices. Palaeogeography, Palaeoclimatology, Palaeoecology. vol 461: 224-236. doi: https://doi.org/10.1016/j.palaeo.2016.08.027.

Isik K. 2011. Rare and endemic species: why are they prone to extinction?. Turkish Journal of Botany. vol 35: 411-417. doi: https://doi.org/10.3906/bot1012-90.

Kappes H, Haase P. 2012. Slow, but steady dispersal of freshwater molluscs. Aquatic Sciences. vol 74:114. https://doi.org/10.1007/s00027-011-0187-6.

Laidlaw FF. 1954. Notes on species of the genus Amphidromus (Mollusca, Pulmonata, Pleurodontidae) from islands lying off the west coast of Sumatra, with descriptions of new races based on collections made by Dr. E. Jacobson in 1913. Zoologische Mededelingen. vol 33(15): 7581.

Laidlaw FF. 1957. Notes on the collection of landmollusca made by Dr. E. Jacobson on the islands of Simalur and Babi in 1913, with descriptions of new species and races. Zoologische Mededelingen. vol 35(10): 125-138.

Liu L, Mondal MHM, Idris MA, Lokman HS, Rajapakse PRVJ, Satrija F, Diaz JL, Upatham ES, Attwood SW. 2010. The phylogeography of Indoplanorbis exustus (Gastropoda: Planorbidae) in Asia.
Parasites and Vectors. vol 3(57): 1-18. doi: https://doi.org/10.1186/1756-3305-3-57.

Marwoto RM, Isnaningsih NR, Joshi RC. 2018. The invasive apple snail (Pomacea spp) in Indonesia. Agriculture for Development. vol 35: 41-48.

Mujiono N. 2016. Gastropoda mangrove dari Pulau Lombok, Nusa Tenggara Barat. Oseanologi dan Limnologi di Indonesia. vol 1(3): 39-50. doi: http://dx.doi.org/10.14203/oldi.2016.v1i3.55.

Nurinsiyah AS, Hausdorf B. 2019. Listing, impact assessment and prioritization of introduced land snail and slug speciesin Indonesia. Journal of Molluscan Studies. vol 85(1): 92-102. doi: https://doi.org/10.1093/mollus/eyy062.

Pearce TA, Orstan A. 2006. Terrestrial gastropoda. In: Sturm CF, Pearce TA, Valdes A (eds). The Mollusks: A Guide to Their Study, Collection, and Preservation. Pittsburgh: American Malacological Society. pp. 261-285.

Regnier C, Fontaine B, Bouchet P. 2009. Not knowing, not recording, not listing: numerous unnoticed mollusk extinctions. Conservation Biology. vol 23(5): 1214-1221. doi: https://doi.org/10.1111/j.15231739.2009.01245.x.

Rensch B. 1932. Die Molluskenfauna der Kleinen SundaInseln Bali, Lombok, Sumbawa, Flores und Sumba. II. Zoologische Jahrbücher. Abteilung für Systematik Ökologie und Geographie der Tiere. vol 63: 1-130.

Rohlf FJ, Fisher DL. 1968. Test for hierarchical structure in random data sets. Systematic Zoology. vol 17: 407-412. https://doi.org/10.1093/sysbio/17.4.407.

Saraçli S, Doğan N, Doğan İ. 2013. Comparison of hierarchical cluster analysis methods by cophenetic correlation. Journal of Inequalities and Applications. vol 203: 1-8. doi: https://doi.org/10.1186/1029-242X-2013-203.

Uit de Weerd DR, Gittenberger E. 2019. Range expansion in the land snail species Carinigera buresi (Clausiliidae): long-distance dispersal by ancient marble transport?. Journal of Molluscan Studies. vol 85(2): 204-211. https://doi.org/10.1093/mollus/eyz002.

van Benthem-Jutting WSS. 1952. Systematic studies on the non-marine mollusca of the Indo-Australian Archipelago. III. Critical revision of the Javanese Pulmonate land-snail of the families Ellobiidae to Limacidae, with an appendix on Helicarionidae. Treubia. vol 21(2): 291-435.

van Benthem-Jutting WSS. 1956. Systematic studies on the non-marine mollusca of the Indo-Australian Archipelago. V. Critical revision of the Javanese freshwater gastropod. Treubia.vol 23(2): 259477.

van Benthem-Jutting WSS. 1959. Catalogue of the NonMarine Mollusca of Sumatra and of its Satelitte Islands. Beaufortia. vol 7(83): 41-191. 
van Leeuwen CHA, Huig N, van der Velde G, van Alen TA, Wagemaker CAM, Sherman CDH, Klaassen M, Figuerola J. 2013. How did this snail get here? Several dispersal vectors inferred for an aquatic invasive species. Freshwater Biology. vol 58: 8899. doi: https://doi.org/10.1111/fwb.12041.

Vermeulen JJ, Whitten AJ. 1998. Fauna Malesiana guide to the land snail of Bali. Leiden: Backhuys Publishers. p. 164.

Whitlow KF. 2008. The 2004 and 1861 tsunami deposits on Simeulue island, Western Sumatra. [Thesis]. Washington: Central Washington University. 